\title{
INTERACTION IN EFL WRITING CLASS: LECTURERS' REFLECTION
}

Monalisa

State Islamic University of Sulthan Thaha Saifuddin Jambi, Indonesia

(monalisa@uinjambi.ac.id)

Received: $22^{\text {th }}$ September 2017; Revised: $25^{\text {th }}$ November 2017; Accepted: $28^{\text {th }}$ December 2017

\section{ABSTRACT}

In writing class, producing a well-polished text passes two main stages: pre writing and drafting. During these stages, interactions take place which can be in form of learnerslearners and learners-lecturers interactions. Dealing with this, two main questions should be directed towhat practices of interaction conducted during writing class and how lecturers reflect them. The data were collected from four writing lecturers of English Education Program of State Islamic University Sulthan Thaha Saifudin Jambiwho have at least two years teaching experience. An interview conducted to each of them to explore what interactions were facilitating and less facilitating learners.The result showed that oral and written interaction were found from both learners-learners and learners-lecturers interactions.As reflected by the lecturers, both oral and written interactions made sense for the learners with particular assistances. Specifically, a long written comments on the learners' drafts contributed better revision.

Key Words: Interaction; EFL writing; Reflection

\section{ABSTRAK}

Untuk memproduksi sebuah teks yang terpoles dengan baik, ada dua tahapan utama yang dilalui di kelas Writing yakni tahapan pramenulis dan tahapan membuat draft. Selama tahapan tersebut, interaksi berlangsung antara mahasiswa dengan mahasiswa dan antara dosen dengan mahasiswa. Terkait dengan hal ini, ada dua pertanyaan yang diajukan yakni apa saja praktek interaksi yang terjadi di kelas Writing dan bagaimana dosen merefleksikannya. Data penelitian ini dikumpulkan dari empat orang dosen Writing di program studi pendidikan Bahasa Inggris UIN Sulthan Thaha Saifudddin Jambi yang memiliki pengalaman mengajar paling sedikit dua tahun. Interview dilakukan dengan mereka untuk mengetahui interaksi apa saja yang dapat memfasilitasi mahasiswa dalam menulis. Temuan menunjukkan bahwa terdapat interaksi secara oral dan tertulis dari mahasiswa dengan mahasiswa dan mahasiswa dengan dosen. Seperti yang direfleksikan oleh para dosen, kedua tipe interaksi tersebut bermakna bagi mahasiswa dengan asistensi khusus. Temuan spesifiknya adalah bahwa komentar panjang tertulis pada draft mahasiswa mampu membuat revisi draft mereka menjadi lebih baik.

Kata Kunci: interaksi; EFL writing; Refleksi

How to Cite: Monalisa. (2017). Interaction in EFL Writing Class: Lecturers' Reflection. IJEE (Indonesian Journal of English Education), 4(2), 144-155. doi:10.15408/ijee.v4i2.8323 


\section{INTRODUCTION}

To match the demand of academic and interpersonal functions, writing becomes an essential productive activity for English Foreign Language (EFL) learners to develop.In their academic tasks, EFL learners are very often to report for final project, articles, and thesis. In addition to fulfilling interpersonal function, they will be likely to conduct formal correspondences as providing report to supervisors and clients when they possess certain occupation in the future. Having such aboveproducts are the result of complex andcognitive process which needs sustained intelectual effort over a considerable period of time.The process is recursively to have meaningful language output. Therefore, it facilitates acquisition in L2 writing (Saville-Troike,2006, p.163).

The recursive process of EFL writing accomodatesproceduresin the process writing (Nunan,1999,p.273). At any stage of this process, William (2005) emphasizes that second language learners need much time, more discussion, and feedback. It is in line with Kim (2010) who reveals that learners could deliver their thoughts and meaning closer to the target intention through involving them in collaborative, revising group work in each stage of writing process. Thus, it could be identified thatworking at any stage of process writing requires interaction among learners and teacher formanaging the input and feedback through responding and correcting.

Interaction in the view of of socialcultural theory may boost higher forms of thinking and complex skill. VillamiL \& Guerrero (2006, p.24) believe that a learner who internalizes social interaction with others and the external dialogue with teachers and/or peers becomes internalized, resulting in a 'socially constructed dialogue mind'.It is supported by Slavin (1982) who stresses that learners who are involved in close interaction have an individual accountability to achieve shared goals. The role of interaction insocial approach is further explained by saville-Troike (2006, p.106) below.

From a social perspective, interaction is generally seen as essential in providing learners with the quantity and quality of external linguistic input which is required for internal processsing, in focusing learner attention on aspects of their L2 which differ from target language norms or goals, and in providing collaborative means for learners to build discourse structure and express meaning which are beyond the current level of their linguistic competence. 
Therefore, interaction is viewed as a means of providing input and feedback in the recursive process of producing written works in process writing.

One type of learners-learners interaction is group work in which the intentions are to get more ideas to write, to develop confidence being a writer as well. Working in pair is another type of learner-learner interaction which is commonly known as peer review. It is similar to peer editor as the term used by Oshima and Hogue (2007,p.18). A peer editor is a classmate who reads the draft and helps to improve the content and organization. In this interaction, learners pay attention on each other's draft and give advice and make suggestion about how their drafts could be improved. The strength of group work is due to equal level of the leaerners so that comprehensible input is likely occur and contribute to second or first language learning(Krashen \& Terrel, 1983).

Both in group work and peer review where an interaction may take place, a teacher may play different roles as an examiner, audience, assistant, resource, evaluator, or editor (Harmer, 2006,p.109).Such interactionsare considered quite common in classroom setting. In the process writing, interaction between teacher and learners may occur at pre writing stage, drafting, and revising. In this productive activities, teachers may respond on the learners problems of their relatively limited L2 knowledge, content they wish to communicate, context for a specific communicative situation, and cultural convention for language use. Ellis (2005,p.40) reveals that the opportunity to interact in the L2 is central to developing L2 proficiency. When learners receive input and feedback relevant to their poblems in writing, they have chance to clarify and process (engaging in negotiating for meaning). In this opportunity, they acquire L2 writing.

There are at least three different ways of expressing input and feedback during interaction; they are orally, written comments, and graphic devices.Harmer (2004) suggests to respond orally when the teachers are involved with work -in- progress by visiting students and talking to them about what they are writing. At work in- progress stage,oral interaction commonly occurs in forms of group discussion and pair work in which each member has greater chance of offering different opinions and varied contributions. Furthermore,oral response also likely occur when a learner needs a conference with the teacher at the stage of revising the 
draft. Peres-Amurao (2014) views that holding conference as part of teacher intervention in making use of written input will produce satisfactory final draft.

The second way of providing input and feedback is through written comments or written corrective feedback. Ellis (2009) identifies it as typology of written corrective feedback which consists of direct, indirect, metalinguistic corrective feedback, the focus of the feedback, electronic feedback, and reformulation. Written corrective feedback is a standard method employed by most teachers to provide guidance at revising stage (Karimi, 2016). Harmer (2007) offers responding, correcting, and involving learners to refer to feedback on written work. What he means with responding is to say how the text appears to the teacher and how succesful she thinks it has been. There are two ways of responding: in the form of letter and by showing alternative ways of writing. Then, correcting means using codes to indicate that the learners make mistakes in their written work located into the body of the text itself or in the margin. The learners are trained to benefit it. Lastly, involving learners means to encourage learners to give feedback to each other. Such peer review has possitive effect on group cohesion to be better at self monitoring.
The last is graphic devicesin which Lestari (2008) lists them into underlining, circles, and arrows. In Ellis' (2009) typology, underlining and particular codes which is inserted to correct between two words or two letters on learners draft are included into direct corrective feedbacak. Such providing written input commonly applied by teacher on learners full draft and by their peers at peer review session.

Those three are not always viewed possitevely. As experinced by Lestari (2008), teacher's input and feedback are not in phrase level comment or in the form of oral comments or graphic devices, such as underlining, circles, arrows, etc., yet in paragraph level with written comments. She further explains that oral and short written comments as well as graphic devices are considered less sufficient in providing intake for the progress of the final draft. Graphic devices such as underlining, circles, and arrows are received by students to be more or less a command. This situation tends to place teacher and students unequally which then limits the interactive process. One out of three ideas to make written corrective feedback efficient according to Ferris (2011, p.109) is that the teacher should prefer giving feedback indirectly, focused, and verbally, not bypresenting them with codes or symbols. 
Since learners often receive negative evidence on their drafts, Harmer (2004) believes that it is a good idea to write down something good in the students' works. Such response can be extremely useful and should help them to avoid mistake in their final draft. Moreover, Ellis (2005) identifies that the role of corrective feedback in L2 acquisition is controversial. $\mathrm{He}$ supports this identification by rolling Truscott's (1999) argument out as correcting learners' errors has no effect on learners' acquisition of new L2 forms.

Though Lestari (2008) may overlook the use of graphic devices on providing written comments, Monalisa's (2013) experience allowedher to keep inserting them beside her long written comments on the learners' outlines. Simply put, she fastened the graphic devices with written comment and vice versa. The learners found the contribution and interrelationship of them so that they made use of the two on their works. Moreover, she kept providing oral comments specifically at the step of generating ideas.

A study of practitioner's views on corrective feedback was conducted by Alzahrani (2016). He collected the data through both closed and open ended questionnaire given to ten
English language teachers who four of them are native speakers of English. The results indicate that the teachers believe in effectiveness of coded unfocused corrective feedback toward writing accuracy. However, the participants also believe that using code to mark learners' errors would be more effective if used selectively.

Chen et al. (2016) conducted a case study of university students from Mainland China deal with their perceptions and preferences of written corective feedback. Both quantitative and qualitative data were collected from 64 intermediate, adavancedintermedite, and advanced English learners across three proficiency level. The findings showed that learners expressed a favourable attitude toward error corection. Qualitatively, the participants prefered to revise their products with less teachers' interference.

In relation to types of feedback learners prefer, a study conducted by Hajian et al (2014) found that learners prefer possitive comments more than one types. Most of them prefered detailed and specific comment.

The above discussion motivates the author to investigate what practices of interaction conducted during writing class and how lecturers reflect them. 


\section{METHODS}

The study aimed at having lecturers' reflection on the practices of interaction conducted in their writing class. The participants were four English lecturers coded as L1, L2, L3, L4with at least two year exprerinces in teaching writing. Interviews were conducted around 20 to 30 minutes in the first language settingfor each of them. There were ways of expessing input and feeedback in an interaction derived from ways of reacting to students' writing (Harmer, 2004) which are broken into pieces of questions stated in theinterview protocol. The data collected are aboutwhat practices of interactions conducted and what facilitate and less facilitate learners on lecturers' responding and correcting during interaction at the stage of planning and drafting of students' products. Planning stage consists of choosing a topic, generating ideas through listing, deleting irrelevant ideas, and making outline.The process of text making, peer review, written comment and conference session are included into the drafting stage. The process of analyzing data was preceded by transcribing and translating them into English. The trancripts then were coded and categorized based on the stages practiced in process writing. To go beyond, the discussion is conducted on the basis of relevant theories and related findings.

\section{FINDING AND DISCUSSION}

The findings of this study are presented stage by stage of input and feedback occured in process writing.The first information was obtained from the interview about interaction when choosing a topic. All the interviewees stated that they provided input for the learners and conducted interaction orally. They found that the learners were facilitated.

- Though most of learners were highly interested choosing their own topics, two or three others required me to provide some choices.(L3)

- They loved my assistance for proving topics and discussed how to narrow them.(L1)

- Some learners showed me their topics and asked wether those were likely to be developed. Even their questions were further about cultural convention for L2 use.(L4)

- Having their own topics did not mean they have adequate L2 knowledge to be formulated into correct phrases. They asked me for assistance.(L2)

These statements show that oral interaction at the initial phase turn them into engagment to negotiate for 
meaning.During the interaction, learners got input from the teachers in terms of focusing their attention on aspect of L2 (Saville-Troike, 2006).Teachers play their roles as assistants who help learners along and as resource persons who are available for learners' need on information or guidance (Harmer,2004). Then, situating learners to prefer their own topics is to free themselves from feeling underpressure. Their familiarity to the topics is taken into account to ensure their readiness to next phase of process writing. Therefore, their self confidence are built.

Oral interaction also occurs at generating ideas in pair or in group discussion. It was found that doing brainstorming by listing ideas promoted both learner-learner and learner-teacher interaction to make make sense of the activity as reflected by one of the interviewee below.

I found that learners prefer brainstorming by listing rather than clustering in process of generating ideas. They felt free to express any words, phrases, even sentences directly and inderectly related to the topic. They felt no worry for making mistakes.I allowed them to consult with their dictionary or thesaurus. I went around helping them with suggestions; or they asked me for clarification on particular expressions. When they came into deleting some particular irrelevant ideas, each member of the group delivered their reasons based on their L2 knowledge.(L2)

What author might gain from this statement is that doing brainstorming in a group through listing is considered simpler for the learners. They feel equal since no body dominates the activity. Such feeling becomes significant in consructing the meaning for the work. It is quite similar opinion with Krashen and Terrel (1983) who indicate thatinput from their peers is likely comprehensible and contributes to second language learning as the language level of among group members are roughly equal. In additon, Slavin (1982) emphasizes that the individual accountability to pursue particular goals is maintained in this group work.By allowing them to consult with their dictionary or thesaurus, lecturer trains them not to rely more on their lecturer. However, building learners independence does not mean learners are totally free from lecturers' supervision. Therefore, lecturers keep playing their roles as an audience who responds to the learners' ideas, and as an assistent as well as a resource person.

Both oral and witten comment usually come at the outlining of the draft. These two ways of interaction at this stage are conducted for organizing ideas. This step is considered difficult to 
many learners as describedin the following.

- In completing the ready made scheme of the outline, they are quite often struggling for formulating the main ideas and determined the order of supporting sentences of each paragraph. To facilitate them, I recalled their memory on the theory of how to write a main idea by asking them questions. What I found that they were not happy with more questions. As I realized it, I provided them with a model of good discourse structure of an outline. When the outline was finished, I came to respond their work by circling some misplaced expressions and gave notes at the edge of lines. Some learners got the ideas on the note and were able to improve the outline, but some did not.(L1)

- Learners asked for clarification on the certain codes (arrows, circles) I used to provide feedback to the learners' work. They did not want to revise their work immediately due to many graphic devices throughout the work (L3)

The two statements above show that some learners may get frustrated when they are offered many questions and graphic devices. These cases are in line with Ellis' opinion (2005) on the controvercy of corective feedback. Specifically, having codes and symbol (including circle, arrows) are considered less satisfying strategies for written corrective feedback (Ferris, 2011). It is supported by Lestari (2008), one of whose researchfindings tend to overlook the graphic devices. Some other learners, however, may benefit the graphics since written feedback available as experienced by Monalisa (2013). For those who get used to such symbols, they make sense of them. As Harmer (2007) states that to benefit on the graphic devices and the codes, the learners should be trained firts to use them.

When the learners have revised their outline, they come to the stage of text production. Almost all learners feel comfortable to do drafting individually. It is undestood that the interaction in this stage is fully between the learners as writers and the text. They process all the input given at two previous interactive activities. The input and feedback are managed in central processing stage. In this mental process, input and feedback as the new skills demand learner writer attention, and thusinvolves controlled processing. Before learner writer' full draft is finished as the output, practices are conducted to move to authomatic processing (McLaughlin, 1987 as cited in Saville-Troike, 2006). As the draft is finished, learner writer conducts peer review based on peer review sheet 
guidance. The following statements are from the interviewee.

- I found some learners work better to provide feedback on their peer draft, and some others do not.(L4)

- I took a look to the low volume discussion of two peer during peer review. They explained each other on the contents of the drafts. (L2)

- Mostly learner writers focused their attention on grammar mistake, words, and spelling in peer review. Content, context, and cultural convention of the draft were neglected.(L1)

- Not many corrective feedback given by peer because they thought that there would be lecturer' final respond.(L3)

From the statements above, lecturers have to familiarize learners with this sheet to make sense of this activity. In order to conduct successful peer review, learner writers have to be trained intensively (Farah, 2012, p.199). The learners' familiarity on L2 knowledge (vocabulary, morphology, syntax, discourse structure) bring them to provide respond on words and grammar; having low volume discussion between peer showed that they conducted confirmation check for negociating meaning resulted on correction of each other's errors (Ellis, 1997); they are reluctant to respond on the content and the context of the draft. Thus, learners need to be exposed to requirements of production of written langauge. To produce written language, it does not only require knowledge of L2 but also prior knowledge of content whishes to communicate, context to a specific communication, and cultural conventions for langaugeage use (Saville-Troike, 2006).

As the draft has been revised based on peer responses, it is then submitted to the lecturers for having input and feedback. Here are the information gained by the lecturers along learners' revision of their final draft.

- A number of learners asked me to make an oppoinmant to discuss orally on the short written respond I provided.But some others prefer to work without having conference. (L1)

- I found only small number of learners whose final drafts got little progress under my long written comments. In other words, most of them have better final draft.(L2)

- Some learners were succesfull to revise their works;some others were not. The graphic devices and short writen comment on their drafts for some learners were efficient, but not for some others.(L4)

- I found that a succesful revision made by a learner whose first draft 
considered very poor. I wrote one long good example to her. She learned better from the example.(L3)

From the first case, the authormay identify two inferences. The first is that a short written respons isconsidered less adequate to facilitate better revision. In this case, learning will take place when interaction conducted in written form and orally at the same time. Itis in line with one of the finding in Peres-Amurao' study (2014) in which learners need for conference to uptake of the writen comment. This result is not opposite to the qualitative finding in a study conducted by Chen et al. (2016) whose participants tend to revise their products with less teachers' interference.

The second case shows that long written comments are considered effecttive as it is supported by Lestari's study (2008). It is reasonable, since it may possibly provide much intake for the progress of the final draft.Long written comment might provide teachers enoughopportunity to generate input extensively as supported byAlzahrani's (2016) finding on the effectiveness of coded unfocused corrective feedback on writing accuracy. As it is unfocused feedback, abundant exposures related to L2 knowledge, content, context for particular setting as well as cultural convention are more likely contributed for utilising self-repair.

Next, what author is able to infer from the fourth lecturer's case is that negotiating meaning through graphic devices and short written comments may partly take place. It might be other factors influence learning such as learners' familiarity to the devices or the clarity of short written comment itself.Such less familiarity might direct Ferris (2011) and Lestari (2008) to neglect codes and symbol. In general,short written comments are typical written input of direct unfocused corrective feedback. As a result, learners may not easily solve their linguistic difficulties.A most likely learners' effort to revise their drafts is through acquiring the detailed and specific comment provided by teacher (Hajian et al, 2014).

The last case displays that modelling the draft helps learners more. Imitating is an easy activity. Here the teacher plays her role as fully resource. Hence, it is not a surprise that is from the very poor draft appears the succesful one due to the available model.

\section{CONCLUSION AND SUGGESTION}

A number of ways in interaction during writing class may turn into both facilitating and less facilitating learners 
in producing better final drafts. Oral interaction between learner-learner and teacher-learner interaction in selecting the topic bring them into engage to negotiate meaning. Other interaction that promote learning is long written respond on learners' draft. Peer review will be significant when learners are familiar with the demand of peer review sheet. To facilitate learners interaction with written response on their full draft, familiarity on L2 knowledge (vocabulary, morphology, syntax, discourse structure) bring them to provide respond on words and grammar; learners need to be exposed to prior knowledge of content whishes to communicate, context to a specific communication, and cultural conventions for langaugeage use. Corrective feedback in form of grapich devices will much better accompanied by oral interaction. The graphics are also fastened by written comments. Otherwise, some learners may get frustrated with the "allien" devices.

Other activities come into less sufficient interaction are a bunch of questions to recall learners' memory. Too many lecturer's visitsinto the learners group discussion may put them underpressure. Next, short written respons on final draft is not adequate to facilitate learning. The use of graphic devices and short written comments on full draft may partly promote learning. The last is long written comment in form of providing model text helps learners more. However, modelling is like imitating which does not boost critical thinking. Modelling is still likely suggested to the teachers to take into account with particular teaching approach so that it may benefit learners.

\section{REFERENCES}

Alzahrani, H.F. (2016). Teachers' stated beliefs on coded unfocused corrective feedback in EFL writing at Saudi University. TESOL International Journal, 11(1), 52-63.

Chen, S. Nassaji, H. Liu, Q. (2016). EFL learners' perceptioon and preferences of written corrective feedback: a case study of university students from Mainland China. Asian Pasific Journal of Second and Foreign Language Education, 1(5),1-17.

Ellis, R. (2009). A typology of written corrective feedback types. ELT Journal, 63(2),97-107.

Ellis, R. (2005).Instructed Second Language Acquisition A Literature Review Report To The Ministry of Education. Auckland : UniServices Limited.

Ellis, R. (1997).Second language acquisition. Oxford: Oxford University Press.

Ferris, D.R. (2011). Treatment of error in second language writing (2nd ed). Ann Arbor: Michigan. 
Hajian, L., Farahani, A.A.K,. \& Shirazi, M.A. (2014). A study of students and teachers prefereces and attitudes toward correction of classsroom written error in Iranian EFL context. International Journal of Applied Linguistics and English Literature, 3(5), 287-297.

Harmer, J. (2004).How to teach writing. England: Pearson Education Ltd.

Harmer, J.(2007).The practice of English language teaching(4th ed). England: Pearson Education Ltd.

Karimi, S.H. (2016). Effect of different types of teacher written corective feedback on the Iranian EFL learners' writing accuracy. Journal of Applied Linguistics and Language Research, 3(2):216-229.

Krashen, S.,\& Terrel, T.D. (1983). The natural approach. NY: Pergamon.

Kim, B. G. (2010). Collaborative discussion and peer review activity incomputermediated EFL writing. Multimedia Assisted Language Learning, 13(2), 105128.

Lestari, L.A. (2008). The interactionalapproach to the teaching of writing and itsimplication for secondlanguage acquisition.Teflin Journal, 19 (1): 42-56.

Monalisa. 2013. Feedback to students' writing at planning stage for better final drafts.Reflective. Journal of English Education Program, (4): 8-15.
Nunan, D.(1999). Second language teaching and learning. Boston: Heinle \& Heinle Publishers.

Oshima, A \& Hogue, A. (2007). Introduction to academic writing(3rd ed). White Plains: Pearson Education Inc.

Perez-Amurao, A.L. (2014).The Value of feedback and conferencing in the process approach to writing for Filipino and Thai students in Higher Education: acomparative analysis.TESOL International Journal, 9(2):18-35.

Saville-Troike. Muriel. 2006. Introducing Second Language Acquisition. Cambridge: Cambridge University Press.

Slavin, R.E. (1982). Cooperative learning: students teams. What research says to the teacher?Washington, DC: National Education Asosiation.

Villamil, O.S.,\& de Guerrero, M.C.M. (2006). Sociocultural theory: A framework for understanding sociocognitive dimension of peer feedback. In K.Hyland and F. Hyland (Eds), Feedback in second language writing: Context and issues (21-41). New York: Cambridge University Press.

William, J. (2005). Teaching writing in second and foreign language classrooms. Boston, MA: McGraw-Hill. 10 (1). 